\title{
Implementasi Kebijakan Pemerintah Tentang Prioritas Penggunaan Dana Desa di Desa Talaga Paca Dan Wangongira, Kabupaten Halmahera Utara
}

\author{
Richard Djiko*), Bagus Subardi² \\ ${ }^{1}$ Program Studi Manajemen Bisnis, Politeknik Perdamaian Halmahera, Indonesia \\ ${ }^{2}$ Program Studi Manajemen Bisnis, Politeknik Perdamaian Halmahera, Indonesia
}

\begin{abstract}
This study aims to find out how the implementation of government policies regarding the priority of using village funds for community empowerment and village development activities in the villages of Telaga Paca and Wangongira, North Halmahera Regency. This research use descriptive qualitative approach. Source of data used in this study uses primary and secondary data. From the results of the study it can be concluded that what is mandated by the law is not in line with what is the reality in the field, whether it is development activities and community empowerment. The same thing happened for development activities of those two villages the activities of procurement, development, and maintenance of economic infrastructure to realize the Village Economic Granary has not been carried out well, while the Community empowerment activities are found that the two villages are in community empowerment activities for the development of village information systems. This was not done in the two villages, This is not in line with what is mandated by the Regulation of the Minister of Villages, Development of Disadvantaged Regions, and Transmigration of the Republic of Indonesia.
\end{abstract}

Keywords: Policy Implementation, Village Development, Community Empowerment

\begin{abstract}
Abstrak
Penelitian ini bertujuan untuk mengetahui bagaimana implementasi kebijakan pemerintah tentang prioritas penggunaan dana desa untuk kegiatan pemberdayaan masyarakat dan Pembangunan desa di desa Telaga Paca dan Wangongira Kabupaten Halmahera Utara. Penelitian ini menggunakan pendekatan deskriptif kualitatif. Sumber data yang digunakan dalam penelitian ini menggunakan data primer dan sekunder. Dari hasil penelitian dapat disimpulkan bahwa apa yang menjadi amanat undang-undang belum sejalan dengan apa yang menjadi realita di lapangan baik itu kegiatan pembangunan dan pemberdayaan masyarakat, Untuk kegiatan pembangunan terjadi hal yang sama yaitu di kedua desa tersebut untuk kegiatan pengadaan, pembangunan, pengembangan, dan pemeliharaan sarana prasarana ekonomi untuk mewujudkan Lumbung Ekonomi Desa belum di dilaksanakan dengan baik sedangkan untuk kegiatan pemberdayaan masyarakat yang menjadi temuan adalah di kedua desa tersebut adalah dalam kegiatan pemberdayaan masyarakat untuk kegiatan pengembangan sistem informasi desa. Hal ini tidak di laksanakan di kedua desa tersebut, Ha ini tidak sejalan dengan apa yang menjadi amanat Peraturan Menteri Desa, Pembangunan Daerah Tertinggal, Dan Transmigrasi Republik Indonesia.
\end{abstract}

Kata kunci: Implementasi Kebijakan, Pembangunan Desa, Pemberdayaan Masyarakat 
Kolaborasi : Jurnal Administrasi Publik, April 2020 Volume 6 Nomor 1

\section{PENDAHULUAN}

Implementasi

kebijakan

merupakan tindakan yang dilakukan oleh pemerintah untuk mencapai tujuan yang telah ditetapkan. Pemerintah desa dalam hal ini sebagai pengelola Dana Desa yang harus sebisanya memanfaatkan dana desa untuk pemberdayaan masyarakat dan kegiatan pembangunan yang sesuai dengan program prioritas pemanfaatan dana desa.

Desa merupakan ujung tombak dalam pembangunan nasional. Pembangunan daerah pedesaan menjadi prioritas utama yang terus digalakkan untuk menunjang pembangunan nasional. Dengan adanya otonomi daerah yang diberikan oleh pemerintah pusat kepada daerah melalui kabupaten/kota, sehingga jika dilihat, esensi otonomi daerah, maka daerah di berikan kewenangan untuk mengembangkan daerahnya masing-masing, maka dari pada itu, pemerintah pusat melalui pemerintah daerah memberikan Dana Desa dan Alokasi daa Desa Sebagai Suport terhadap pembangunan pada level pemerintahan di tingkat paling bawah, yaitu desa.

Berdasarkan Peraturan Pemerintah Nomor 60 Tahun 2014 Dana Desa yang bersumber pada APBN bahwa Dana Desa adalah dana yang bersumber dari Anggaran Pendapatan dan Belanja Negara yang diperuntukkan bagi Desa yang ditransfer melalui Anggaran Pendapatan dan Belanja Daerah kabupaten/kota dan digunakan untuk membiayai penyelenggaraan pemerintahan, pelaksanaan pembangunan, pembinaan kemasyarakatan, dan pemberdayaan masyarakat. (Nafidah \& Suryaningtyas, 2015)

Penggunaan Dana Desa pada dasarnya merupakan hak Pemerintah Desa sesuai dengan kewenangan dan prioritas kebutuhan masyarakat desa setempat dengan tetap mengedepankan prinsip keadilan.Setiap desa memiliki kebutuhan yang berbeda, baik di kegiatan pembangunan dan pemberdayaan masyarakat.

Di dalam peraturan Peraturan Menteri Desa, Pembangunan Daerah Tertinggal, Dan Transmigrasi Republik Indonesia Nomor 19 Tahun 2017 pasal 1 ayat 8 menjelaskan bahwa Pembangunan Desa adalah upaya peningkatan kualitas hidup dan kehidupan untuk sebesar-besarnya kesejahteraan masyarakat Desa.

Menurut Nugrohodan Rochmin Dahuri yang dalam (GARIS, 2017) bahwa pembangunan dapat diartikan sebagai suatu upaya terkoordinasi untuk 
Kolaborasi : Jurnal Administrasi Publik, April 2020 Volume 6 Nomor 1

menciptakan alternatif yang lebih banyak secara sah kepada setiap warga negara untuk memenuhi dan mencapai aspirasinya yang paling manusiawi. Sedangkan menurut (Nafidah \& Suryaningtyas, 2015), Pembangunan masyarakat pedesaan diartikan sebagai aktivitas yang dilakukan oleh masyarakat dimana mereka mengidentifikasikan kebutuhan dan masalahnya Bersama. Selain terkait dengan pembangunan, yang menjadi program prioritas dalam dana desa adalah kegiatan program pemberdayaan masyarakat.

Di dalam Permendesa nomor 5 Tahun 2015 tentang penetapan prioritas penggunaan dana desa bahwa Pemberdayaan Masyarakat Desa adalah upaya mengembangkan kemandirian dan kesejahteraan masyarakat dengan meningkatkan pengetahuan, sikap, keterampilan, perilaku, kemampuan, kesadaran, serta memanfaatkan sumber daya melalui penetapan kebijakan, program, kegiatan, dan pendampingan yang sesuai dengan esensi masalah dan prioritas kebutuhan masyarakat Desa. (Nafidah \& Suryaningtyas, 2015)

Sedangkan Menurut Adisasmita (2013,). (Karimah, Saleh, \& Wanusmawatie, 2014) pemberdayaan masyarakat adalah upaya pemanfaatan dan pengelolaan sumber daya masyarakat perdesaan secara lebih efektif dan efisien, baik dari (a) aspek masukan atau input (sumberdaya manusia, dana, peralatan/sarana, data, rencana, dan teknologi; (b) dari aspek proses (pelaksanaan, monitoring, dan pengawasan); (c) dari aspek keluaran atau output (pencapaian sasaran, efektivitas, dan efisiensi).

Berdasarkan Peraturan Menteri Desa, Pembangunan Daerah Tertinggal, Dan Transmigrasi Republik Indonesia nomor 19 Tahun 2017 Tentang Penetapan Prioritas Penggunaan Dana Desa Tahun 2018. Selain mengedepankan prinsip keadilan di dalam peraturan ini juga mengatur tentang program prioritas Pemanfaatan dana desa lebih di fokuskan kepada pembangunan dan pemberdayaan masyarakat.

Berdasarkan hasil pengamatan awal penulis di kedua desa tersebut, bahwa pemerintah lebih banyak memanfaatkan dana desa belum sesuai dengan amanat undang-undang diatas, sehingga hal ini menarik di kaji, karena pergeseran desa menjadi desa yang otonom, sehingga desa berhak untuk mengatur rumah tangganya sendiri. Pengakuan otonomi desa ini didukung oleh Undang-Undang Nomor 23 Tahun 
Kolaborasi : Jurnal Administrasi Publik, April 2020 Volume 6 Nomor 1

2014 tentang Pemerintahan Daerah dan Undang-Undang Nomor 33 Tahun 2004 tentang Perimbangan Keuangan antara Pemerintah Pusat dan Daerah. Hal ini di maksudkan agar daerah atau desa tersebut mampu untuk mengatur apa yang menjadi kebutuhan desa tersebut, berdasarkan apa yang menjadi kebutuhan masyarakatnya yang sesuai dengan ketentuan peraturan perundangundangan.

Perwujudan kemandirian desa didukung pula dengan lahirnya UndangUndang Nomor 6 Tahun 2014 tentang Desa sehingga kedudukan desa menjadi lebih kuat dan menjadi bagian terdepan dari upaya pembangunan yang berasal dari prakarsa masyarakat. Berdasarkan Undang-Undang Nomor 6 Tahun 2014 tentang Desa pasal 18, kewenangan desa meliputi kewenangan di bidang penyelenggaraan pemerintahan desa, pelaksanaan pembangunan desa, pembinaan kemasyarakatan desa, dan pemberdayaan masyarakat desa berdasarkan prakarsa masyarakat, hak asal usul, dan adat istiadat. (Noviyanti, Gamaputra, Lestari, \& Utami, 2018).

\section{METODE PENELITIAN}

Penelitian ini menggunakan pendekatan deskriptif kualitatif. Deskriptif kualitatif yaitu suatu prosedur penelitian yang menggunakan data deskriptif berupa kata-kata tertulis atau lisan dari orang-orang dan pelaku yang dapat diamati. (Garis, 2017). Sumber data yang digunakan dalam penelitian ini menggunakan data primer dan sekunder. Data primer di dapat melalui wawancara. Di dalam penelitian ini informan ditentukan sejak awal penelitian.Informan penelitian ditentukan secara (purposive sampling). Hal ini dimaksudkan agar untuk memilih informan yang benar-benar relevan dan kompeten dengan masalah penelitian sehingga data yang diperoleh dapat dipergunakan untuk membangun kesimpulan. Informan yang di berkompeten di dalam penelitian ini adalah Kepala Desa, sekretaris desa, bendahara desa, Kaur, ketua-ketua RT, ketua dan anggota BPD, tokoh masyarakat, dan masyarakat. Data sekunder dalam penelitian ini adalah data di dapat dari dokumen-dokumen yang ada di lokasi penelitian penelitian dalam hal ini data yang ada di pemerintah desa. Data sekunder lainnya adalah data yang di dapat di lokasi penelitian yaitu bukti kegiatan pemanfaatan dana desa di lokasi penelitian.

Dalam Penelitian ini analisis data dilakukan sejak awal sepanjang 
Kolaborasi : Jurnal Administrasi Publik, April 2020 Volume 6 Nomor 1

proses penelitian. Dalam penelitian ini alanalisis data kualitatif digunakan model interactive model dari Miles dan Huberman.Dengan prosesdur, data direduksi, penyajian data dan penarikan kesimpulan/verivikasi data.(Karimah, Saleh, \& Wanusmawatie, 2014).

\section{HASIL DAN PEMBAHASAN}

Di dalam penelitian ini mengkaji tentang Implementasi Kebijakan Pemerintah tentang Prioritas Penggunaan Dana Desa di Desa Telaga Paca Dan Wangongira, mengacu pada Peraturan Menteri Desa, Pembangunan Daerah Tertinggal, Dan Transmigrasi Republik Indonesia Nomor 19 Tahun 2017 Tentang Penetapan Prioritas Penggunaan Dana Desa Tahun 2018 pasal 4, ayat (1) Prioritas Penggunaan Dana Desa untuk membiayai pelaksanaan program dan kegiatan di bidang pembangunan Desa dan pemberdayaan masyarakat Desa.

Di dalam pasal 5.Dana Desa digunakan untuk membiayai pembangunan Desa yang ditujukan untuk meningkatkan kesejahteraan masyarakat Desa, peningkatan kualitas hidup manusia serta penanggulangan kemiskinan dengan prioritas penggunaan Dana Desa.
Di dalam Peraturan Pemerintah Nomor 60 Tahun 2014 Dana Desa yang bersumber pada APBN bahwa Dana Desa adalah dana yang bersumber dari Anggaran Pendapatan dan Belanja Negara yang diperuntukkan bagi Desa yang ditransfer melalui Anggaran Pendapatan dan Belanja Daerah kabupaten/kota dan digunakan untuk membiayai penyelenggaraan pemerintahan, pelaksanaan pembangunan, pembinaan kemasyarakatan, dan pemberdayaan masyarakat. (Nafidah \& Suryaningtyas, 2015).

\section{Pemberdayaaan Masyarakat}

Di dalam Permendesa nomor 5 Tahun 2015 tentang penetapan prioritas penggunaan dana desa bahwa Pemberdayaan Masyarakat Desa adalah upaya mengembangkan kemandirian dan kesejahteraan masyarakat dengan meningkatkan pengetahuan, sikap, keterampilan, perilaku, kemampuan, kesadaran, serta memanfaatkan sumber daya melalui penetapan kebijakan, program, kegiatan, dan pendampingan yang sesuai dengan esensi masalah dan prioritas kebutuhan masyarakat Desa. (Nafidah \& Suryaningtyas, 2015)

Pandangan lain yang tidak jauh berbeda yang di kemukakan oleh Adisasmita (2013,). (Karimah et al., 
Kolaborasi : Jurnal Administrasi Publik, April 2020 Volume 6 Nomor 1

2014) pemberdayaan masyarakat adalah upaya pemanfaatan dan pengelolaan sumber daya masyarakat perdesaan secara lebih efektif dan efisien, baik dari (a) aspek masukan atau input (sumberdaya manusia, dana, peralatan/sarana, data, rencana, dan teknologi; (b) dari aspek proses (pelaksanaan, monitoring, dan pengawasan); (c) dari aspek keluaran atau output (pencapaian sasaran, efektivitas, dan efisiensi).

Salah satu fokus pemanfaatan dana desa adalah untuk kegiatan pemberdayaan masyarakat. Berdasarkan data sekunder yang di dapat di lokasi penelitian untuk tahun 2018 desa Telaga Paca mendapatkan Anggaran untuk kegiatan pengabdian masyarakat berjumlah Rp. 246,824,650. Dan untuk desa Wangongira pada tahun 2018 mendapatkan anggaran untuk kegiatan pemberdayaan masyarakat berjumlah Rp. 141.289.502.

Berdasarkan data ini menjelaskan bahwa di kedua desa tersebut mendapatkan topangan dana dari pemerintah untuk kegiatan pemberdayaan masyarakat, namun berdasarkan data sekunder untuk kegiatan pemberdayaan masyarakat di ke dua desa tersebut.
Tabel 1.

Rincian Kegiatan Pemberdayaan Masyarakat Desa Wangongira Tahun anggaran 2018

Rincian Kegiatan Pemdes

Belanja kegiatan bimtek PEMDES

Belanja kegiatan pemilihan BPD

Belanja kegiatan operasional paud

Belanja pembay. Insentif kader Kesehatan

Belanja Pelatihan Kader Kesehatan

Belanja Pelatihan Kader PKK

Belanja Insentif Guru PAUD

Belanja Kursus Komputer

Belanja Pembibitan Pala

Belanja Penguatan BUMDes Belanja

Kegiatan Musrenbang desa

Belanja Kegiatan Operasional PKK

Belanja Alat Pertukangan

Sumber: Peraturan kepala desa Wangongira nomor 01 Tahun 2018 tentang penjabaran anggaran pendapatan dan belanja desa tahun anggaran 2018.

Tabel 2.

Rincian Kegiatan Pemberdayaan Masyarakat Desa Telaga Paca Tahun anggaran 2018

\begin{tabular}{l}
\hline \multicolumn{3}{c}{ Rincian Kegiatan Pemdes } \\
\hline Kegiatan Pelatihan Kepala \\
Desa dan Perangkat \\
Kegiatan Peningkatan \\
Kapasitas Lembaga Masyarakat \\
Kegiatan Pemberdayaan \\
Posyandu, UP2K dan BKB \\
Kegiatan Kampanye dan \\
Promosi Hidup Sehat \\
\hline Insentif Untuk Kader \\
\hline
\end{tabular}


Kolaborasi : Jurnal Administrasi Publik, April 2020 Volume 6 Nomor 1

Kesehatan Masyarakat

Kegiatan bantuan insentif guru paud

Kegiatan Penyelenggaraan

kursus seni budaya

\begin{tabular}{lr}
\hline Kegiatan & bantuan \\
Pemberdayaan & Bidang \\
Olahraga & \\
\hline
\end{tabular}

Kegiatan Pembersihan aliran

Sungai

Kegiatan Penyusunan Arah

Pengembangan Desa

Kegiatan Penyusunan

Rancangan Program/Kegiatan

Pembangunan Desa. yang

berkelanjutan

Kegiatan Penyelenggaraan

Musyawarah Desa

Kegiatan Pengembangan

Sistem Administrasi Keuangan

dan Aset Desa Berbasis Data

Digital

Kegiatan Pembentukan dan

Pelatihan Kader Pemberdayaan

Masyarakat

Pelaksanaan suatu kebijakan merupakan suatu hal yang penting bahkan lebih penting dari pada pembuatan kebijakan, Udoji. (Mustanir \& Darmiah, 2016), jika di lihat dari konsep ini, apa yang di muat dalam Peraturan Menteri Desa, Pembangunan Daerah Tertinggal, Dan Transmigrasi Republik Indonesia Nomor 19 Tahun 2017. Kebijakan itu tidak hanya di buat, akan tetapi bagaimana menjalankan kebijakan tersebut. Realita keadaan dilapangan tidak selalu sama dengan apa yang menjadi apa yang diharapkan pemerintah, karena setiap desa memiliki kebutuhan yang berbeda.
Jika di lihat dari ke dua data sekunder diatas jika di sandingkan dengan apa yang menjadi amanat di dalam Peraturan Menteri Desa, Pembangunan Daerah Tertinggal, Dan Transmigrasi Republik Indonesia Nomor 19 Tahun 2017 Tentang Penetapan Prioritas Penggunaan Dana Desa Tahun 2018 pasal 7 ayat 1 menjelaskan bahwa Dana Desa digunakan untuk membiayai program dan kegiatan bidang Pemberdayaan Masyarakat Desa yang ditujukan untuk meningkatkan kapasitas dan kapabilitas masyarakat Desa dengan mendayagunakan potensi dan sumber dayanya sendiri sehingga Desa dapat menghidupi dirinya secara mandiri.

Di dalam Tabel 1 untuk kegiatan pemberdayaan masyarakat di desa Wangongira diatas terlihat bahwa kegiatan-kegiatan Pemerintah desa yang tertuang di dalam peraturan kepala desa belum semua sesuai dengan apa yang menjadi amanat regulasi, sesuai dengan Peraturan Menteri Desa, Pembangunan Daerah Tertinggal, Dan Transmigrasi Republik Indonesia Nomor 19 Tahun 2017 Tentang Penetapan Prioritas Penggunaan Dana Desa Tahun 2018 Pasal 7 Ayat 2 bagian d, yaitu pengelolaan dan pengembangan sistem informasi desa. Sesuai data diatas 
Kolaborasi : Jurnal Administrasi Publik, April 2020 Volume 6 Nomor 1

terlihat bahwa kegiatan pemdes belum sejalan dengan apa yang menjadi amanat regulasi. Namun yang tertuang di dalam Peraturan Menteri Desa, Pembangunan Daerah Tertinggal, Dan Transmigrasi Republik Indonesia Nomor 19 Tahun 2017 Tentang Penetapan Prioritas Penggunaan Dana Desa Tahun 2018 Pasal 7 Ayat 2 menjelaskan bahwa pengembangan sistem informasi desa merupakan suatu program prioritas dalam pembangunan di desa. Hal yang sama pun terjadi di desa Telaga Paca, bahwa kegiatan pemerintah desa untuk pengembangan sistem informasi belum di laksanakan.

Jika di lihat dalam peraturan ini maka masih saja ada kebijakan yang di buat di dalam desa belum sepenuhnya sesuai dengan apa yang tertuang dalam peraturan ini, belum sepenuhnya di jalankan oleh desa, namun kita harus lihat bahwa di dalam Undang-undang mengatur bahwa desa adalah suatu yang otonom, sehingga desa berhak mengatur/mengurus rumah tangganya sendiri, sehingga terkadang apa yang di atur dalam peraturan belum sesuai dengan kebutuhan di lapangan.

\section{Pembangunan Desa}

Implementasi berkenaan dengan pelaksanaan berbagai kegiatan yang diarahkan pada realisasiprogram. Di dalam tulisan ini menbahas tentang bagaimana realisasi program pembangunan. Pembangunan bisa saja diartikan berbeda oleh satu orang dengan orang lain, daerah yang satu dengan daerah yang lain, negara satu dengan negara lain. Namun secara umum ada satu kesepakatan bahwa pembangunan merupakan proses untuk melakukan perubahan (Riyadi Dan Deddy Supriyadi Bratakusumah, 2005).(Garis, 2017) Di desa Telaga Paca mendapatkan Dana Desa untuk kegiatan pembangunan sebesar Rp. 574.075.497 dan Wangongira pada tahun 2018 mendapatkan anggaran untuk kegiatan pembangunan desa sebesar Rp. 390.483.350, berikut perincian kegiatan untuk pembangunan di kedua desa tersebut.

\section{Tabel 3.}

Rincian Kegiatan Pembangunan Desa Telaga Paca Tahun anggaran 2018

\begin{tabular}{l}
\hline \multicolumn{1}{c}{ Rincian Kegiatan Pemdes } \\
\hline Pembangunan Drainase \\
\hline $\begin{array}{l}\text { Pembangunan Jalan desa antar } \\
\text { pemukiman }\end{array}$ \\
Pembangunan Gorong-gorong \\
$\begin{array}{l}\text { Pembangunan air bersih } \\
\text { berskala desa }\end{array}$ \\
\hline Pembangunan MCK \\
$\begin{array}{l}\text { Pengadaan buku dan peralatan } \\
\text { belajar mengahar }\end{array}$ \\
\hline
\end{tabular}


Kolaborasi : Jurnal Administrasi Publik, April 2020 Volume 6 Nomor 1

Untuk desa Wangongira berikut perincian kegiatan pemanfaaan dana desa untuk kegiatan pembangunan.

\section{Tabel 4.}

Rincian Kegiatan Pembangunan Desa Wangongira Tahun anggaran 2018

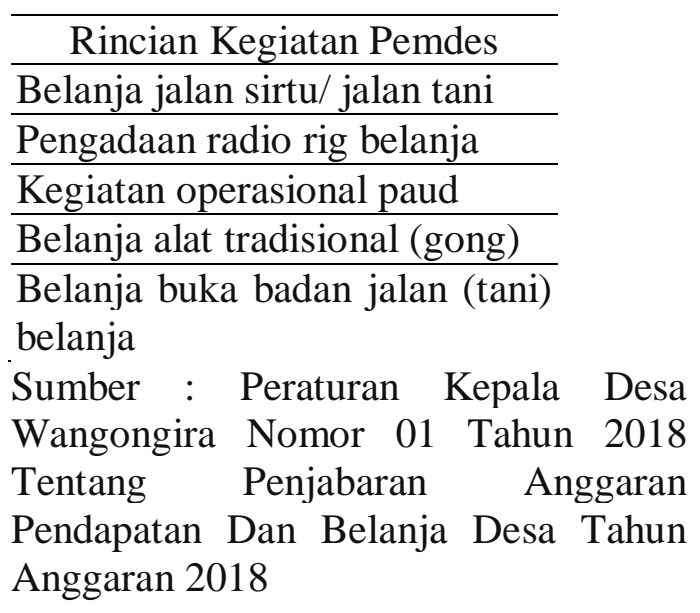

$$
\text { Impelementasi kebijakan }
$$

menurut Van Meter dan van Horn yang dikutip oleh Parsons (1995: 461) (AKIB, 2010) bahwa implementasi kebijakan merupakan tindakan yang dilakukan oleh (organisasi) pemerintah dan swasta baik secara individu maupun secara kelompok yang dimaksudkan untuk mencapai tujuan. Penjelasan ini menyatakan bahwa pelaksanaan kebijakan yang telah di buat baik itu pihak swasta maupun pemerintah akan di jalankan untuk mencapai tujuan.

$$
\text { Menurut (Nafidah \& }
$$

Suryaningtyas, 2015), Pembangunan masyarakat pedesaan diartikan sebagai aktivitas yang dilakukan oleh masyarakat dimana mereka mengidentifikasikan kebutuhan dan masalahnya Bersama.

Kegiatan pembangunan desa ditujukan untuk memenuhi kebutuhan dasar di dalam desa tersebut. Di desa Telaga Paca dan desa Wangongira pada tahun 2018 di dalam RKP Maupun RPJM desa merencanakan untuk kegiatan seperti yang tertuang di dalam rincian kegiatan pemdes untuk kegiatan pembangunan di tahun 2018.

Dari data sekunder pada Tabel 3 dapat di jelaskan bahwa kegiatan pembangunan di desa Telaga paca belum sejalan dengan apa yang menjadi amanat regulasi, lebih khusus untuk pembangunan dan pengembangan Lumbung ekonomi desa, yakni untuk kegiatan usaha ekonomi pertanian. Di dalam Peraturan Menteri Desa, Pembangunan Daerah Tertinggal, Dan Transmigrasi Republik Indonesia Nomor 19 Tahun 2017 Tentang Penetapan Prioritas Penggunaan Dana Desa Tahun 2018 Pasal 5 Bagian C Menjelaskan Bahwa Salah Satu Prioritas Penggunaan Dana Desa Untuk Kegiatan Pembangunan Adalah Untuk Kegiatan Pengadaan, Pembangunan, Pengembangan, Dan Pemeliharaan Sarana Prasarana Ekonomi Untuk Mewujudkan Lumbung Ekonomi Desa, meliputi: (1) usaha ekonomi pertanian 
Kolaborasi : Jurnal Administrasi Publik, April 2020 Volume 6 Nomor 1

berskala produktif untuk ketahanan pangan;

(2) usaha ekonomi pertanian berskala produktif meliputi aspek produksi, distribusi dan pemasaran yang difokuskan kepada pembentukan dan pengembangan produk unggulan desa dan/atau produk unggulan kawasan perdesaan; dan (3) usaha ekonomi non pertanian berskala produktif meliputi aspek produksi, distribusi dan pemasaran yang difokuskan kepada pembentukan dan pengembangan produk unggulan desa dan/atau produk unggulan kawasan perdesaan. Sedangkan untuk desa Wangongira terjadi hal yang sama, yaitu kegiatan pembangunan belum sejalan dengan apa yang menjadi amanat undang-undang yaitu untuk kegiatan kegiatan pengadaan, pembangunan, pengembangan, dan pemeliharaan sarana prasarana ekonomi untuk mewujudkan Lumbung Ekonomi Desa

\section{KESIMPULAN}

Berdasarkan permasalahan yang diteliti. Peneliti berusaha mengungkapkan fenomena atau kejadian yang ditemukan dilapangan dan peneliti menyimpulkan sebagai berikut :Bahwa apa yang menjadi amanat undangundang belum sejalan dengan apa yang menjadi realita di lapangan baik itu kegiatan pembangunan dan pember- dayaan masyarakat. Untuk kegiatan pembangunan terjadi hal yang sama yaitu di kedua desa tersebut untuk kegiatan pengadaan, pembangunan, pengembangan, dan pemeliharaan sarana prasarana ekonomi untuk mewujudkan Lumbung Ekonomi Desa belum di dalaksanakan sesuai dengan amanat Permendesa no 19 Tahun 2017 Pasal 5 bagian $\mathrm{C}$, sedangkan untuk kegiatan pemberdayaan masyarakat yang menjadi temuan adalah di kedua desa tersebut dalam kegiatan pemberdayaan masyarakat untuk kegiatan pengembangan sistem informasi desa. Ha ini tidak sejalan dengan apa yang menjadi amanat Peraturan Menteri Desa, Pembangunan Daerah Tertinggal, Dan Transmigrasi Republik Indonesia Nomor 19 Tahun 2017 Tentang Penetapan Prioritas Penggunaan Dana Desa Tahun 2018 Pasal 7 Ayat 2, yaitu pengembangan system Infomasi Desa.

\section{UCAPAN TERIMA KASIH}

Terimah Kasih yang sebesarbesarnya kepada Kemenristekdikti yang telah memberikan kepercayaan kepada penulis sehingga telah memberikan Hibah Penelitian Dosen Pemula Tahun anggaran 2019. 
Kolaborasi : Jurnal Administrasi Publik, April 2020 Volume 6 Nomor 1

DAFTAR PUSTAKA

AKIB, H. (2010). IMPLEMENTASI

KEBIJAKAN: Apa, Mengapa, dan

Bagaimana HAEDAR AKIB.

Jurnal Administrasi Publik, 1(1), $1-11$.

Garis, R. R. (2017). ANALISIS

IMPLEMENTASI 4 PROGRAM

PRIORITAS KEMENTERIAN

DESA PEMBANGUNAN

DAERAH TERTINGGAL DAN

TRANSMIGRASI DI

KABUPATEN CIAMIS (Studi

kasus pada lima desa di kabupaten

Ciamis). MODERAT: Jurnal Ilmu

Pemerintahan, 3(2), 108-130.

Retrieved from

https://jurnal.unigal.ac.id/index.ph

p/moderat/article/view/689

Karimah, F., Saleh, C., \&

Wanusmawatie, I. (2014).

DALAM PEMBERDAYAAN

MASYARAKAT ( Studi pada

Desa Deket Kulon Kecamatan

Deket Kabupaten Lamongan ).

Jurnal Administrasi Publik, 2(4),

597-602. Retrieved from

administrasipublik.studentjournal.u

b.ac.id/index.php/jap/article/downl

oad/428/312

Mustanir, A., \& Darmiah. (2016).
Implementasi kebijakan dana desa

dan partisipasi masyarakat dalam pembangunan di desa teteaji kecamatan tellu limpoe kabupaten sidenreng rappang. Jurnal Politik Profetik, 04(2), 226-238.

Nafidah, L. N., \& Suryaningtyas, M. (2015). Akuntabilitas Pengelolaan Alokasi Dana Desa Dalam Upaya Meningkatkan Pembangunan Dan Pemberdayaan Masyarakat. Jurnal Bisnis Dan Manajemen Islam, 3(1), 1-25. Retrieved from http://journal.stainkudus.ac.id/inde x.php/Bisnis/article/view/1480

Noviyanti, Gamaputra, G., Lestari, Y., \& Utami, D. A. (2018). PENGIDENTIFIKASIAN PENDAPATAN DAN PRIORITAS PENGGUNAAN DANA DESA. Publisia: Jurnal Ilmu Administrasi Publik, 3(2), 112-121. Retrieved from http://jurnal.unmer.ac.id/index.php/ jkpp/article/view/2378/pdf

Peraturan Kepala Desa Wangongira Nomor 01 Tahun 2018 Tentang Penjabaran Anggaran Pendapatan Dan Belanja Desa Tahun Anggaran 2018. Unpublished 